\title{
Freshwater autotrophic picoplankton: a review
}

\author{
Cristiana CALLIERI* and John G. STOCKNER ${ }^{1)}$ \\ CNR -Istituto per lo Studio degli Ecosistemi, Largo Tonolli 50, 28922 Pallanza, Italy \\ 1) Eco-Logic Ltd. 2614 Mathers Avenue, W. Vancouver, British Columbia Canada \\ *e-mail corresponding author: c.callieri@iii.to.cnr.it
}

\begin{abstract}
Autotrophic picoplankton (APP) are distributed worldwide and are ubiquitous in all types of lakes of varying trophic state. APP are major players in carbon production in all aquatic ecosystems, including extreme environments such as cold ice-covered and/or warm tropical lakes and thermal springs. They often form the base of complex microbial food webs, becoming prey for a multitude of protozoan and micro-invertebrate grazers, that effectively channel APP carbon to higher trophic levels including fish. In this review we examine the existing literature on freshwater autotrophic picoplankton, setting recent findings and current ecological issues within an historic framework, and include a description of the occurrence and distribution of both single-cell and colonial APP (picocyanobacteria) in different types of lakes. In this review we place considerable emphasis on methodology and ecology, including sampling, counting, preservation, molecular techniques, measurement of photosynthesis, and include extensive comment on their important role in microbial food webs. The model outlined by Stockner of an increase of APP abundance and biomass and a decrease of its relative importance with the increase of phosphorus concentration in lakes has been widely accepted, and only recently confirmed in marine and freshwater ecosystems. Nevertheless the relationship which drives the APP presence and importance in lakes of differing trophic status appears with considerable variation so we must conclude that the success of APP in oligotrophic lakes worldwide is not a certainty but highly probable.
\end{abstract}

Key words: autotrophic picoplankton, APP, picocyanobacteria, lakes

\section{INTRODUCTION}

\subsection{Freshwater picoplankton}

Planktonic organisms can be subdivided based on physiological, taxonomic (Malone 1980; Stockner \& Antia 1986 ) or dimensional criteria (Dussart 1965; Sieburth et al. 1978). A basic classification of plankton is: bacterioplankton (constituted mainly by heterotrophic prokaryotes), phytoplankton (includes cyanobacteria and eukaryotes), zooplankton (formed by eukaryotic unicellular and pluricellular organisms). Coincident with this subdivision, there is the criterion of separating organisms by size. Perhaps the simplest scheme is that of Dussart (1965) who divided plankton on a logarithmic size scale: macroplankton $(200-2000 \mu \mathrm{m})$, microplankton $(20-200 \mu \mathrm{m})$, nanoplankton $(2-20 \mu \mathrm{m})$. Sieburth et al. (1978) elaborated this classification scheme and added the terms picoplankton $(0.2-2 \mu \mathrm{m})$ and femtoplankton $(0.02-0.2 \mu \mathrm{m})$. Other terms prevalent in the literature are net plankton, ultraplankton and other categories presented by Sicko-Goad \& Stoermer (1984) and here reported in table 1 .

Picoplankton includes prokaryotic (picocyanobacteria) and eukaryotic phototrophs and heterotrophs (Fig. 1); they are distributed worldwide and are ubiquitous in all types of lakes and trophic state (Stockner 1991). The criteria used to distinguish autotrophs from heterotrophs are the presence of photosynthetic pigments in the former and their capacity to show autofluorescence, which enables their enumeration under epifluorescence mi- croscopy (Davis \& Sieburth 1982). Bacteria or heterotrophic picoplankton must be stained to be visible under epifluorescence.

An extensive literature has documented the great importance played by the activity of algae in the size of picoplankton in global primary production of aquatic ecosystems (Craig 1985; Stockner \& Antia 1986; Stockner 1988). In oligotrophic lakes, from $50 \%$ to $70 \%$ of the carbon fixed annually is attributed to organisms that pass through 1-2 $\mu \mathrm{m}$ pore size filters (Caron et al. 1985; Munawar \& Fahnenstiel 1982). The smaller heterotrophic cells (bacteria) are far more numerous and contribute considerably more to total picoplanktonic biovolume than autotrophic cells (Pick \& Caron 1987; Malinsky-Rushansky \& Berman 1991; Callieri \& Pinolini 1995). In oligotrophic dimictic lakes, picoplankton is capable of remarkable production and subsequent recycling of DOM, when predators and concentrations of limiting nutrients hinder competition of other phytoplankters (Porter et al. 1988). The activity of autotrophic and heterotrophic picoplankton constitutes an important source of energy in the microbial loop (Pomeroy 1974; Azam et al. 1983), and provides a linkage among DOC, nutrients and conventional food webs through the predator-prey interactions of protozoa-picoplankton.

\subsection{Historical and methodological perspectives}

The presence of small planktonic organisms $(<20$ $\mu \mathrm{m})$ was first recognized by Lohmann (1911), who called these organisms nanoplankton. Later, Rodhe 
Tab. 1. Classification of plankton of microscopic and submicroscopic size (From Sicko-Goad \& Stoermer 1984, modified).

\begin{tabular}{lcl}
\hline Terminology & Size & References \\
\hline Net plankton & $>45 \mu \mathrm{m}$ & Throndsen 1978 \\
Microplankton & $>64 \mu \mathrm{m}$ & Vollenweider et al. 1974, Ross \& Duthie 1981 \\
& $20-200 \mu \mathrm{m}$ & Dussart 1965, Sieburth et al. 1978 \\
$50-500 \mu \mathrm{m}$ & Margalef 1955 \\
Nanoplankton & $60-500 \mu \mathrm{m}$ & Hutchinson 1967 \\
& $2-20 \mu \mathrm{m}$ & Dussart 1965, Sieburth et al. 1978 \\
& $5-50 \mu \mathrm{m}$ & Margalef 1955 \\
& $5-60 \mu \mathrm{m}$ & Hutchinson 1967 \\
& $<45 \mu \mathrm{m}$ & Throndsen 1978 \\
& $<100 \mu \mathrm{m}$ & Rodhe 1958 \\
& $<64 \mu \mathrm{m}$ & Vollenweider et al. 1974 \\
Ultrananoplankton & $15-64 \mu \mathrm{m}$ & Ross \& Duthie 1981 \\
Ultraplankton & $<2 \mu \mathrm{m}$ & Dussart 1966 \\
& $<5 \mu \mathrm{m}$ & Margalef 1955 \\
& $0.5-5 \mu \mathrm{m}$ & Hutchinson 1967 \\
& $1-10 \mu \mathrm{m}$ & Throndsen 1978 \\
& $1-15 \mu \mathrm{m}$ & Reynolds 1973 \\
& $<15 \mu \mathrm{m}$ & Ross \& Duthie 1981 \\
Picoplankton & $0.2-2 \mu \mathrm{m}$ & Sieburth et al. 1978 \\
Femtoplankton & $0.02-0.2$ & Sieburth et al. 1978 \\
\hline
\end{tabular}

(1955) described a group of algae of minute size found in subartic Swedish lakes, the " $\mu$-algae". Algae in this size range also have been described as "little round green things" (LRGT) or small coccoid or Chlorellalike cells (Pearl 1977). Verduin (1956) showed experimentally that a large part of photosynthetic activity in lakes was done by organisms passing through a $64 \mu \mathrm{m}$ mesh plankton net, and Bailey-Watts et al. (1968) focussed his limnological studies on small cyanobacteria (picoplankton), a major component of both nutrient and carbon fluxes. Yet, it was only in 1970s and 1980s, thanks to the new techniques of epifluorescence microscopy (Daley \& Hobbie 1975), flow citometry (Olson et al.1985; Chisholm et al. 1988), electron microscopy (Johnson \& Sieburth 1982; Takahashi \& Hori 1984), immunofluorescence techniques (Campbell \& Iturriaga 1988; Shapiro et al. 1989) and chromatographic analysis of pigments (Gieskes \& Kraay 1983; Hooks et al. 1988), that major advances in APP ecology, physiology and taxonomy were made. Thereafter, it was possible to quantify APP routinely, distinguishing phototrophic cells from aplastidic ones, by utilizing the natural autofluorescence of phycobiliprotein pigments and chlorophyll. Two cell-types have been found: yellow autofluorescing phycoerythrin cells (PE) and red autofluoresceing phycocyanin cells (PC) displaying maximum pigment activities at $570 \mathrm{~nm}$ and $630 \mathrm{~nm}$, respectively (Wood et al. 1985; Callieri et al. 1996).

The fluorescent characteristics of picocyanobacteria, based on phycobiliprotein spectra, have proven to be an easy way for their classification (McMurter \& Pick 1994). For example, the difference between PE and PC- containing Synechococcus spp. is evident from fluorescence emission spectra: PE show an emission maximum at $578 \mathrm{~nm}$ when excited at $520 \mathrm{~nm}$, while PC emit maximally at $648 \mathrm{~nm}$ when excited at $600 \mathrm{~nm}$ (Ernst 1991; Callieri et al. 1996).

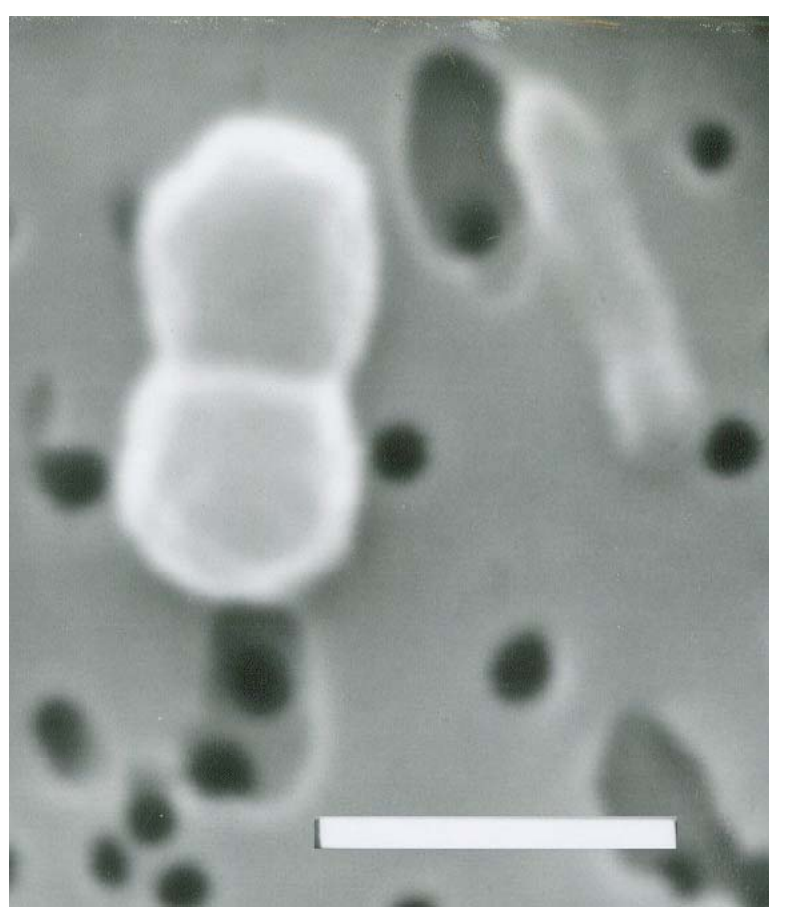

Fig. 1. Photomicrograph of a picocyanobacterium and a bacterium taken with scanning electron microscope (SEM). 18,300 magnification, scale bar is $1 \mu \mathrm{m}$. Photo by C.Callieri. 
The use of flow cytometry led to the discovery of a primitive, prokaryotic picocyanobacteria of the Prochlorophyta group (Chisholm et al. 1988), with divinyl chlorophyll- $a$ (chl- $\left.a_{2}\right)$ as the principal light-harvesting pigment, and divinyl chlorophyll $\mathrm{b}\left(\mathrm{chl}-b_{2}\right)$, zeaxanthin, alfa-carotene and a chl-c-like pigment as the main accessory pigments (Goericke \& Repeta 1993). The small coccoid prochlorophyte species Prochlorococcus marinus is abundant in the North Atlantic Ocean (Veldhuis \& Kraay 1990), the tropical and subtropical Pacific (Campbell et al. 1994), the Mediterranean Sea (Vaulot et al. 1990) and the Red Sea (Veldhuis \& Kraay 1993). In freshwater, only a filamentous form of prochlorophyte has been described from a eutrophic lake (BurgerWiersma et al. 1986; Burger-Wiersma 1991). The other published occurrences of possible prochlorophytes in freshwaters (Stockner \& Antia 1986; Fahnenstiel et al. 1991b) were more likely PC-rich cyanobacteria and Chlorella-like eukaryotic cells.

\section{CURRENT METHODS FOR THE STUDY OF AUTOTROPHIC PICOPLANKTON}

\subsection{Sampling, preservation and enumeration}

Due to their ubiquity, APP are common components of the euphotic zone of lakes, but their distribution and abundance can change dramatically, depending on the interplay of biotic and abiotic factors (Weisse \& Kenter 1991; Hall \& Vincent 1994). It is therefore extremely important that investigators have a broad limnological knowledge of the study lake and take at minimum two subsamples as an optimal sampling strategy in microbial enumeration (Kirchman 1993).

Sample preservation is necessary if using Utermöhl chamber to observe small aggregates and colonies or if interested in single cells from concentrated samples on a membrane filter. Sedimentation of all aggregates of APP cells in the counting chamber is possible only when the cells are preserved with Lugol's solution or other fixatives, because of their buoyancy, which in living cells prevent sinking (Smayda 1974; Wetzel \& Likens 1990). Despite fixation, cells in the pico- size range do not sediment and must be enumerated after filtration on a membrane. APP must be fixed prior to enumeration by epifluorescence for two main reasons: 1) the addition of the proper fixative prevents cell destruction, and 2) ensures rapid settling of cells into the thin oil layer between the membrane and coverslip.

Nevertheless, water samples fixed either with formaldehyde or glutaraldehyde and kept refrigerated in the dark cannot be maintained for long. In the literature, there is still no agreement as to the most appropriate preservatives to use. Hall (1991) compared six methods of phycobilin and chlorophyll- $a$ preservation and obtained the best results by freezing samples at $-20{ }^{\circ} \mathrm{C}$ after addition of paraformaldehyde $(0.2 \%)$. KuuppoLeinikki \& Kuosa (1989) suggest freezing the water sample at $-24{ }^{\circ} \mathrm{C}$ without any preservatives. Glutaralde- hyde has been criticized because its low fixing capacity for chlorophyll- $a$ and phycoerythrin (Bloem et al. 1986); this could be due to the slow penetration time and to the limited effect it has on chloroplast proteins (Park et al. 1966). Recently, McIsaac \& Stockner (1993) summarized the different fixation protocols using both formaldehyde and glutaraldehyde. As often happens when dealing with biological samples, it is best to test in advance the fixing agent on the specific sample of interest.

When comparing the different sample preservation techniques, it appears that the results strongly depend on picoplankton community composition, and therefore, if eukaryotes are numerous in the sample, one should use formaldehyde and immediately count the sample. If dealing with the interactions of picoplankton with nanoflagellates and ciliates in the microbial food web, glutaraldehyde is preferred by electron microscopists for its properties of low shrinkage and maintainance of flagella and cilia structure (Hayat 1981).

When counting picocyanobacteria from oligotrophic and mesotrophic lakes, good results have been obtained adding 20\% formaldehyde buffered with sodium cacodylate $0.1 \mathrm{M}$ (Hayat 1981) to reach the $1 \%$ final concentration in the water sample. The use of $20 \%$ formaldehyde has the advantage of being less stressful for the cells than the $40 \%$ solution, and it is not so diluted as to necessitate addition of a large fixative volume, which could exert considerable osmotic effects. The sodium cacodylate buffer contains arsenic, completely kills heterotrophic picoplankton and maintains the $\mathrm{pH}$ of the solution around 7 (Hayat 1981). The samples must be counted within one week to be sure of not losing pigment fluorescence.

There are three types of filters commonly in use for picoplankton enumeration: aluminum oxide filters (Anopore), nucleation-track polycarbonate membranes (Nuclepore, Unipore, etc.) and organic polymer membranes (Sartorius, Millipore, etc.). Anopore provides the highest retention of small particles (Stockner et al.1990; McKenzie et al. 1992) and promotes a more homogeneous distribution of picocyanobacteria on the filter surface. Anopore $0.2 \mu \mathrm{m}$ filters are commercially available also without the polypropylene ring, and this version should be selected both because they can be mounted on the slide without problems with the coverslip and without the organic ring, they can be used for $\mathrm{CHN}$ analyses as well.

In addition Anopore filters do not need to be blackened in order to observe autofluoresceing cells, because without staining (Acridine Orange or DAPI), background fluorescence is very low. The other two types of membranes are commercially available in black or can be stained by soaking in Irgalan black solution (MacIsaac \& Stockner 1993) or better by coating with a thin layer of gold-palladium (Bertoni \& Callieri 1989). During filtration, it is very important to use a vacuum 
pressure of around 5 - $10 \mathrm{kPa}$ (Kuuppo-Leinikki \& Kuosa 1989; MacIsaac \& Stockner 1993) in order both to obtain an even distribution of cells on the membrane and to have a high collection efficiency. The retention ability under vacuum pressure appears to be influenced by other variables such as cell size, density, flexibility etc. (Li 1986; Stockner et al. 1990).

One disadvantage of the Anopore filter is its brittleness thus care must be taken in handling it. Filters must be dried thoroughly after removal from the holder, then placed on a slide directly on a small drop of $50 \%$ glycerol-water solution, using forceps. An additional drop of glycerol is then added followed by a coverslip. The slide is then turned and pressed slightly on a cleaning paper to absorb the excess glycerol. At this point, it is possible either to count picocyanobacteria cells on the filter after addition of Cargille FF immersion oil or to immediately freeze the slide for long-term storage (MacIsaac \& Stockner 1993).

Picocyanobacteria can easily be observed by epifluorescence miscroscopy under blue (BP450-490, FT510, LP520) and green (LP510-KP560, FT580, LP590) excitation. Basically, autofluorescence of the photosynthetic pigments (chlorophylls and phycobilins) is the result of concordance of the excitation wavelengths with optimum light absorbtion. It is therefore very important to use the suitable filter combinations with epifluorescence microscopy (MacIsaac \& Stockner 1993). The yellow-orange PE should be counted separately from the red $\mathrm{PC}$ because their relative abundance is strongly dependent upon the trophic state of the sampled lake.

\subsection{Genetic diversity of isolates}

Complete taxonomy of picocyanobacteria necessitates use of genetic methods for differentiation of individual strains. One method used for this procedure is the restriction fragment-length polymorphism (RFLP) of the DNA (Douglas \& Carr 1988; Wood \& Townsend 1990; Ernst et al. 1995). An internal fragment of the gene is used as a probe; for example, the pbsA gene (refers to a protein of photosystem II) has been used successfully (Ernst et al. 1995). The probe recognizes the homologous genes and provides information about regions of the genome. DNA must be digested with restriction endonucleases and the fragments separated. By capillary transfer, the denaturated DNA fragments are transferred to nylon membranes and left overnight with the probe for hybridization. The bound probe is recognized by an antibody coupled with alkaline phosphatase, then detected using colorimetric substrates. With this method, a high number of picocyanobacteria clones has been distinguished in Lake Constance, Germany, of which one persisted for a year (Postius et al. 1996).

The use of classical methods based on morphology in combination with molecular techniques based on molecular markers offer one of the best solution to pi- cocyanobacteria identification. Genetic fingerprinting techniques, such as denaturing gradient gel electrophoresis (DGGE) (Muyzer 1999), provide a profile of community diversity based upon physical separation of unique nucleic acids. A polyphasic approach (Vandamme et al. 1996), encompassing the isolation of morphotypes and their molecular characterization, will in the future result in a well defined DNA micro-array able to detect species and strain succession in different environments.

\subsection{Primary productivity}

Primary productivity of APP can be measured by the ${ }^{14} \mathrm{C}$ technique (Steeman Nielsen 1951, 1952); dark bottle measurements are generally substituted by the "time 0 " organic ${ }^{14} \mathrm{C}$ by adding the isotope to the dark bottle and immediately filtering and analysing (Fahnenstiel et al. 1994). The samples are incubated in $150 \mathrm{ml}$ light bottles (in oligotrophic lakes they are labelled with 5 $\mu \mathrm{Ci}$ of $\mathrm{NaH}^{14} \mathrm{CO}_{3}$ ) in situ at five or more depths in the euphotic zone for 4 hours bracketing noon. After incubation, subsamples must be immediately filtered first through $2 \mu \mathrm{m}$ (gravity filtration) then $0.2 \mu \mathrm{m}$ pore size polycarbonate filters (Nucleopore, Costar). The filters are acidified (by adding $200 \mu \mathrm{HCl} 1 \mathrm{~N}$ ) and left one hour uncovered under a fume hood. Radioactivity of the sample is measured in a conventional scintillation counter.

For the calculation of the primary productivity at each depth, the following formula is used (Danish Standard Association 1982, modified):

$$
P P=\left[L B-\left(\text { o.r. } \times \frac{T A_{L B}}{T A_{\text {o.r. }}}\right)\right] \times \operatorname{tot} C i \times 1.05 \times 1.06 \times \frac{1000}{T A_{L B} \times \Delta t}
$$

where:

$P P=$ primary productivity $\left(\mathrm{mgC} \mathrm{m}^{-3} \mathrm{~h}^{-1}\right)$;

$L B=$ activity in the light bottle (d.p.m. $\mathrm{ml}^{-1}$ );

o.r. = activity of the organic residual in the dark bottle (d.p.m. $\mathrm{ml}^{-1}$ );

tot $C i=$ total inorganic carbon $\left(\mathrm{mg} \mathrm{l}^{-1}\right)$;

$1.05=$ correction factor for slower assimilation of ${ }^{14} \mathrm{C}$ with respect to ${ }^{12} \mathrm{C}$;

$1.06=$ correction factor for respiration of assimilated ${ }^{14} \mathrm{C}$;

$T A_{L B}=$ total activity of the LB (d.p.m. $\mathrm{ml}^{-1}$ );

$T A_{\text {o.r. }}=$ total activity of the organic residual in the dark bottle (d.p.m. $\mathrm{ml}^{-1}$ );

$\Delta t=$ incubation time (in hours).

To obtain the daily area-integrated total productivity of the euphotic zone $\left(\mathrm{mg} \mathrm{C} \mathrm{m} \mathrm{C}^{-2}\right)$, a factor must be calculated for the extrapolation of the measurement from the 4 hour incubation to total photoperiod. Among the different methods (Gächter 1972; Vollenweider 1965; Platt 1971), the most utilized is Platt's factor, calculated as follows: 


$$
F=\frac{1}{\lambda} \times\left\{\Delta t+\left[\frac{\lambda}{\pi} \times \sin \left(\frac{\Delta t}{\lambda} \times \pi\right)\right]\right\}
$$

where:

$\Delta t=$ incubation time in hours;

$\lambda=$ length of the day in hours.

Daily productivity is calculated by dividing the areaintegrated total production during the incubation period $\left(\mathrm{PP}_{\Delta t}\right)$ by the $F$ factor:

$$
P_{d a y}\left(m g C m^{-2} d^{-1}\right)=\frac{P P_{\Delta t}}{F}
$$

Photosynthetic parameters and a description of $P / I$ curves are provided in Eilers \& Peeters (1988). They developed a dynamic model which describes the relationship between light intensity and photosynthesis on the base of the velocity and probability of transition among the stationary, activated and inhibited states of the photo-systems. The relationship between photosynthesis $(P)$ and intensity of radiation $(I)$ is the following:

$$
P=\frac{I}{a I^{2}+b I+c}
$$

When $I$ is low, $a I^{2}$ and $b I$ can be neglected and production rate increases approximately linearly with radiation intensity, while at high intensities $a I^{2}$ prevails and production rate is inversely proportional to the intensity. Eilers \& Peeters (1988) obtained the photosynthetic parameters of $P / I$ curves as follows:

$$
\begin{gathered}
\alpha=\frac{1}{c} ; \quad I_{m}=\sqrt{\frac{a}{c}} \\
P_{\max }=\frac{1}{b+2 \sqrt{a c}} ; \quad I_{k}=\frac{c}{b+2 \sqrt{a c}}
\end{gathered}
$$

where:

$\alpha=$ maximum light utilization coefficient, i.e. the assimilation per unit chlorophyll and unit radiation;

$I_{m}=$ is the optimal intensity measured at $P_{\max }$;

$P_{\max }=$ maximum photosynthetic rate per unit chlorophyll;

$I_{k}=$ light saturation parameter.

\subsection{Grazing}

The study of picoplanktivory has developed principally in the last decade, and rates of APP removal by grazers have been measured using different techniques. There is general consensus of using the method of fluorescently labeled particles when microspheres have been substituted by fluorescent marked bacteria and cyanobacteria (FLB \& FLC) (Sherr et al. 1991; Sherr \& Sherr 1993). Epstein \& Rossel (1995) used a new vital fluorescent dye, CTC (5-cyano-2,3-ditolyl tetrazolium chloride), that is non-toxic for bacteria and does not immobilize cells. Furthermore, its does not require heat-killing of the cells as is the case when using the common dye DTAF (5-(4,6-diclorotriazin-2-yl) aminofluorescein). Metabolic inhibitors also have been used successfully: the eukaryote inhibitors colchicine and cyclohexamide stopped protozoan grazing activity on picocyanobacteria (Caron et al. 1991) as well as ampicillin (Campbell \& Carpenter 1986). Liu et al. (1995) found kanamicin to be an effective growth inhibitor of Synechococcus and Prochlorococcus, enabling them to estimate growth and grazing rates. With this new approach picocyanobacteria grazing mortality has been estimated as 43 to $87 \%$ of gross production in marine systems (Liu et al. 1995).

Landry et al. (1995) proposed a refined dilution technique to overcome the assumption that grazing impact varies in direct proportion to dilution of grazer population density. In the new protocol, they introduced fluorescent labeled cells and flow cytometry to measure relative grazing activity in each dilution treatment. Other methods used to estimate picoplanktivory are radioisotope-labeled prey (Iturriaga \& Mitchell 1986) and direct cell counts (Waterbury et al. 1986).

\section{AUTOTROPHIC SPECIES COMPOSITION}

Autotrophic picoplankton is a size classification thus species composition can vary from lake to lake. Prokaryotic bacterial picoplankton are generally dominant over eukaryotic APP and have received more attention from taxonomists in recent years (Komárek 1996). The simple morphology of picocyanobacteria necessitate cytomorphological, ecophysiological and biochemical methods for determining genera and species. To date, three clearly delimited genera of single-cell picocyanobacteria have been defined: Cyanobium, Synechococcus and Cyanothece dianae/cedrorum-type (Komárek 1996). The most common is Cyanobium, which is a small (1-2 $\mu \mathrm{m}$ long, $1 \mu \mathrm{m}$ wide), spherical to oval cell without mucilage. The majority of the "Synechococcustype strains" cited in literature belong to this genera; on

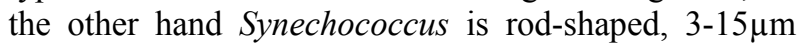
long and $1-3 \mu \mathrm{m}$ wide.

The genetic diversity among picocyanobacteria single-celled forms has indicated the presence of high species diversity during the peak of abundance of the annual cycle in Lake Costance, Germany (Ernst et al. 1995). It is too early to delineate a succession of picocyanobacteria strains mirroring the commonly quoted phytoplankton species succession along seasonal and trophic gradients, but a genetic approach, coupled with study of the ultra-structural characteristics, could be the most successful way of developing this.

Discovery of a regularly ordered globular protein layer (S-layer) of genetically distinguished picocyanobacteria, which could give them functional advantages over cells without surface protection (Ernst et al. 1996), has led to technical approaches to define species composition of the single-celled forms of picocyanobacteria and to understand their success and succession. 
Lakes of different trophic conditions develop small aggregates or colonies composed of picocyanobacteria that functionally must be included in APP as they do not form blooms and their individual cells are of the proper pico- dimensions. Some of the most common colonial picocyanobacteria in freshwaters are species of the genera Aphanocapsa, Aphanothece, Chroococcus, Coelosphaerium, Cyanodictyon, Merismopedia, Snowella and Tetrarcus. The transition forms between true colonies and single morphotypes are, on the other hand, difficult to identify.

A recent review on this subject lists the most common picocyanobacterial species of colonial and solitary forms found in different aquatic environments (Stockner et al. 2000a), and points out the need for a more integrated study of the ecology of single forms and colonial non-bloom-forming picocyanobacteria in order to delineate their role in the microbial food webs of lakes and ponds.

The most commonly reported eukaryote APP is Chlorella-like cells that are generally within the picoplankton size range. Among diatoms (Bacillariophyceae), small Cyclotella and Stephanodiscus cells have been found within the upper size limit of picoplankton $(2-3 \mu \mathrm{m})$, thus at the border of nanoplankton (Callieri \& Pinolini 1995). Three species of eukaryotic green algae were identified in Lake Stechlin, Germany (Padisák et al. 1997): Choricystis minor, Neocystis diplococca and Pseudodictyosphaerium jurisii, the latter two being colonial.

\section{ECOLOGY OF AUTOTROPHIC PICOPLANKTON}

\subsection{Occurrence and distribution of single-cell and colonial picocyanobacteria and eukaryote APP}

APP have been found in a variety of freshwater systems, including ultra-oligotrophic lakes like Lake Baikal, Russia (Boraas et al. 1991), those of high altitude (Hawley \& Whitton 1991; Ruggiu et al. 1998), in polar and subpolar lakes (Vincent 2000), and shallow eutrophic lakes or ponds (Vörös et al. 1998). Despite their wide distribution, there is a pronounced difference in APP species composition along trophic gradients and seasonally within a lake. Single-cell picocyanobacteria are very abundant in oligo- to mesotrophic lakes, while colonial forms occur mostly in meso- to eutrophic lakes or ponds (Stockner et al. 2000a). Eukaryotic APP are generally an order of magnitude less than picocyanobacteria (Burns \& Stockner 1991), and in temperate regions, tend to show peak abundance in spring or early summer during isothermal conditions of $5-10{ }^{\circ} \mathrm{C}$ (Pick \& Agbeti 1991; Fahnenstiel et al. 1991a; Weisse 1993). Eukaryotic cells dominate APP in acidic dystrophic and eutrophic lakes (Stockner \& Shortreed 1991; Søndergaard 1991). Apparently, picoeukaryotes progressively replace picoprokaryotes in lakes with increasing nutrient concentrations and decreasing $\mathrm{pH}$.
The model outlined by Stockner (1991) of an increase of APP abundance and biomass and decrease of its relative importance with the increase of phosphorus concentration in lakes has been widely accepted and recently confirmed in marine and freshwater systems (Bell \& Kalff 2001). Using the extensive freshwater data base of Vörös et al. (1998), we found a relationship between the APP numbers and their contribution to total phytoplankton biomass (Chl) within a broad trophic gradient (Fig. 2). Nevertheless the relationship which drives the APP presence and importance in lakes of differing trophic status appears with a considerable variation so that we must conclude that the success of APP in oligotrophic lakes is not a certainty but only a potentiality (Stockner et al. 2000a). Schallenberg \& Burns (2001) found that picocyanobacteria in oligotrophic lakes are early indicators of changes in trophic status but that they can respond in complex ways to nutrient enrichment.

The typical seasonal cycle of picocyanobacteria shows a bimodal pattern with a spring or early summer peak and a second peak during autumn. In Lake Constance (Weisse \& Kenter 1991; Gaedke \& Weisse 1998) and Stechlin, Germany (Padisák et al. 1997), the strong influence of the spring mixing period and subsequent stratification were responsible for interannual variation of APP dynamics and a deep-layer APP maximum. Likely, the decline of the spring peak is not determined by grazing, but by a short-term destabilization of the water column stratification coupled with nutrient depletion and competition with larger phytoplankton (Weisse 1993; Callieri \& Stockner 2000).

Picocyanobacteria aggregates of different size (4 to 10 up to 50 cells) have been observed in lakes (Vörös et al. 1991; Pick \& Agbeti 1991; Stockner \& Shortreed 1991), and they tend to be more abundant in the epilimnion in August and September, during periods of nutrient limitation (Klut \& Stockner 1991; Passoni \& Callieri 2000). The presence of loose or tightly clustered colonies may have an adaptive function, both in increasing the efficiency of nutrient recycling and in providing protection against predators (Klut \& Stockner 1991). The production of sticky exopolymeric substances could be the first phase of clump formation (Kiørboe \& Hansen 1993). Picocyanobacteria with distinct genotypes have glycoproteins regularly ordered to form S-layers on the cell surface (Ernst et al. 1996). Such a protective coat could be involved in cell adhesion and colony formation, and small aggregates are considered true components of the APP community, often comprising $>50 \%$ of the APP biomass (Stockner \& Shortreed 1991), and therefore should be enumerated as number of cells/colony in future studies. Recently the occurrence of colonial picoeukaryotic species potentially belonging to APP has been reported in Lake Stechlin, Germany (Padisák et al. 1997). 

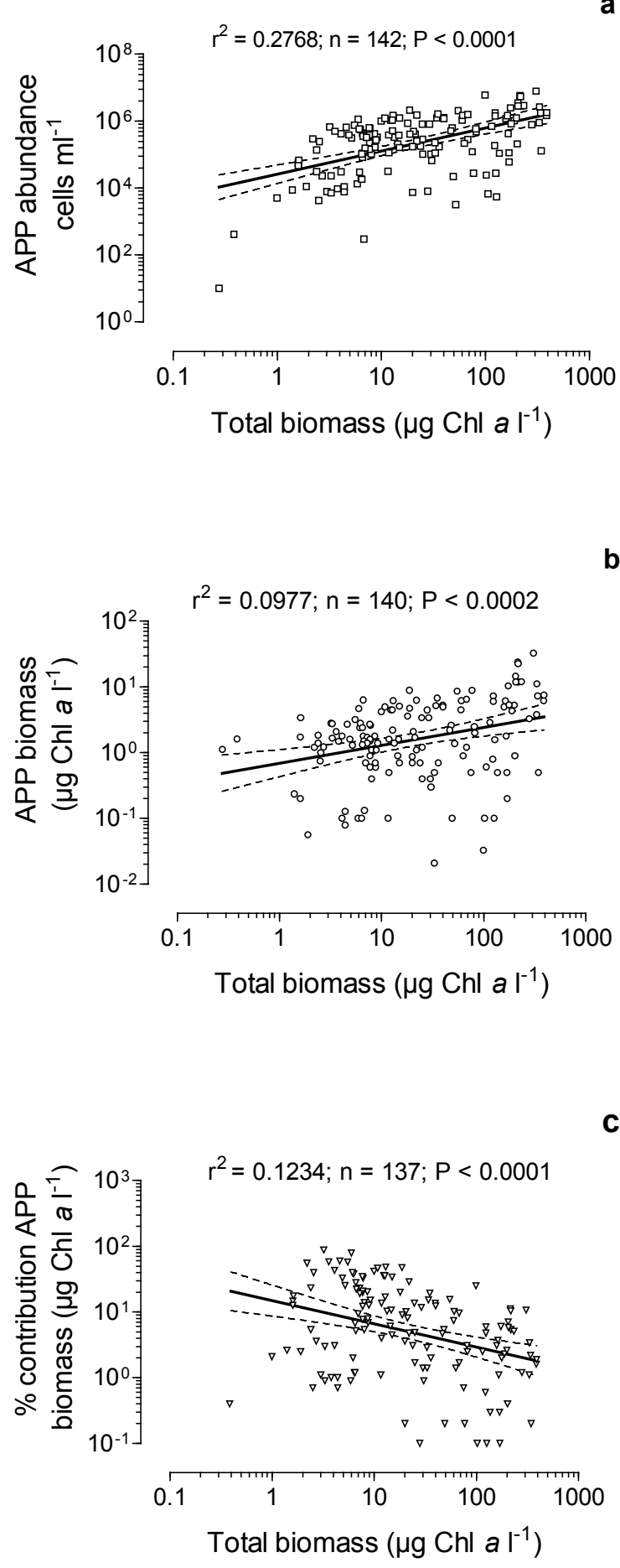

Fig. 2. Relationship between total phytoplankton biomass ( $\mu \mathrm{g}$ Chl- $a \mathrm{l}^{-1}$ ) and a) APP abundance (cells $\mathrm{ml}^{-1}$ ), b) APP biomass $\left(\mu \mathrm{g} \mathrm{Chl}-a \mathrm{l}^{-1}\right)$ and $\mathbf{c}$ ) percent contribution of APP biomass to total phytoplankton biomass.

During thermal stratification, APP profiles have displayed a maximum in the surface water of Lake Biwa, Japan (Maeda et al. 1992), in the epilimnion in Lake Kinneret, Israel (Malinsky-Rushanski et al. 1995), in the metalimnion in Lakes Constance, Maggiore, Stechlin and Baikal (Weisse \& Schweizer 1991; Callieri \& Pinolini 1995; Padisák et al. 1997; Nagata et al. 1994) and in metalimnion or upper hypolimnion in Lakes Huron and Michigan (Fahnenstiel \& Carrick 1992). In Lago Maggiore the deepening of the thermocline in June and July segregates APP in the metalimnion and upper hypolimnion and prevents the spread of APP cells to the epilimnetic layer (Callieri \& Piscia 2002). In this lake the spatial distribution of APP abundance and production followed the isotherms of $18{ }^{\circ} \mathrm{C}$ and $20^{\circ} \mathrm{C}$, and was strictly related to water stratification and thermocline appearance. Further, the APP efficiency (mgC (mg $\mathrm{Chl})^{-1} / \mathrm{Em}^{-2}$ ) had its maximum at the bottom of the euphotic zone, with irradiance in the range $0.5-18 \mu \mathrm{E}$ $\mathrm{m}^{-2} \mathrm{~s}^{-1}$ (Callieri \& Piscia 2002). Though lake thermal structure seems to be an important deterministic factor, a generalization of its relationships with APP abundance is difficult to validate, and the variability from lake to lake may also be related to climatic conditions, other physical characteristics, (e.g. underwater light climate), or to biological interactions, (e.g. competition and predation).

There is good experimental evidence to suggest a low light optima for Synechococcus growth (between 25 and $35 \mu \mathrm{E} \mathrm{m}^{-2} \mathrm{~s}^{-1}$, Waterbury et al. 1986), and in situ lake studies suggest a vertical distribution of picocyanobacteria related to light penetration (Pick \& Agbeti 1991). Generally, APP show maxima at depths with $25-$ $50 \% \mathrm{I}_{0}$ (light intensity penetrating the surface) in large, deep clear lakes (e.g. Passoni et al. 1997), but there is also an indication of the importance of the light quality in addition to light quantity (Vörös et al. 1998). The selective properties of underwater light climate on the selection of different strains of picocyanobacteria could also explain why APP maxima have been found at a variety of depths and light intensities in different lakes (Pick 1991; Callieri 1996). It is clear that pico-phytoplankton composition, (e.g. ratio prokaryotic/eukaryotic, colonial/single), could in large part be responsible for the variety of responses of APP to light, and therefore of their vertical distribution in lakes. Changes in light availability or light quality favor certain species and alter community structure, giving rise to a sudden peak of abundance (Wall \& Briand 1979). In addition, cell size distributions of phytoplankton may also be affected by nutrients and light. APP may outcompete larger cells at greater depths in clear oligotrophic lakes because these cells are less affected by $\mathrm{P}$ limitation than other species and possess greater competitive abilities under low light levels (Wehr 1993).

\subsection{Production, growth and grazing}

Photosynthetic carbon uptake of phytoplankton is affected by nutrient availability, underwater light regime and water temperature. Small unicellular algae in the size range of picoplankton can outcompete larger ones at the oligotrophic extreme of the trophic gradient. One 
of the advantages of small cell-size in low nutrient environments is reduced limitation by molecular diffusion of nutrients (Chisholm 1992), through increased surfaceto-volume ratios (Raven 1986). The simple prokaryotic cell structure of picocyanobacteria, which are the main APP component in most lakes and oceans, has a low cost of metabolic maintenance thus providing a greater chance for success, particularly in oligotrophic lakes (Weisse 1993).

Unfortunately, there is a paucity of data on seasonality of freshwater APP primary productivity (Fahnenstiel \& Carrick 1992; Weisse \& Schweizer 1991; Padisák et al. 1997). In addition, the relative contribution of APP to total phytoplankton production is rarely based on frequent samplings during a seasonal cycle, but is an average of the summer or occasional samplings. Some studies reported an inverse relationship between the picoplankton contribution to total carbon fixation and lake trophic state (Petersen 1991; Bell \& Kalff 2001), while others demonstrated a high APP contribution to total phytoplanktonic production in eutrophic lakes (Vörös et al. 1991) and a low contribution (17\%) in oligotrophic lakes (Fahnenstiel \& Carrick 1992). The highest percentages of APP productivity have been measured in Lake Baikal, where $80 \%$ of ${ }^{14} \mathrm{C}$ uptake was in the $<3 \mu \mathrm{m}$ size fraction (Nagata et al. 1994). In eleven oligotrophic lakes of western Canada, the relative contribution of picoplankton to total photosynthesis ranged from 29 to 53\% (Stockner \& Shortreed 1991; 1994), in Lake Constance, Germany, the ${ }^{14} \mathrm{C}$ incorporation varied between 0.1 and $7.5 \mathrm{mg} \mathrm{C} \mathrm{m}^{-3} \mathrm{~h}^{-1}$ with a relative contribution of $5-65 \%$ to total production. In oligotrophic Lago Maggiore (northern Italy), annual carbon fixation of APP was $16 \mathrm{gC} \mathrm{m}^{-2} \mathrm{y}^{-1}$ in 1994 and $41.2 \mathrm{gC} \mathrm{m}^{-2} \mathrm{y}^{-1}$ in 1998 , accounting for respectively $10 \%$ and $20 \%$ of total phototrophic productivity (Callieri \& Piscia 2002).

The two processes of cell growth (production of biomass) and cell division (production of new cells) are tightly coupled, as photosynthesis and growth rate are light dependent (Kana \& Glibert 1987a; Kana \& Glibert 1987b; Chisholm et al. 1986). There is good laboratory experimental evidence of light influence on APP growth rate for freshwater Synechococcus strains (Fahnenstiel et al. 1991c). Diel changes in the frequency of dividing cells (FDC) of picocyanobacteria were correlated with the day-night light cycle (Pick \& Bérubé 1992), and Callieri et al. (1996) report that cell division reaches a maximum in the afternoon triggering an increase in the cell number, which then proceeds in the dark. However, other studies present evidence that circadian rhythms operate in Synechococcus species (Huang et al. 1990; Kondo et al. 1993), and suggest that cell activities are not directly dependent on the day-night cycle but on an endogenous circadian clock (Sweeney \& Borgese 1989).

Kana \& Glibert $(1987 \mathrm{a}, \mathrm{b})$ measured growth rates at light intensities up to $2000 \mu \mathrm{Em}^{-2} \mathrm{~s}^{-1}$, demonstrating that growth rate became light saturated at $200 \mu \mathrm{Em}^{-2} \mathrm{~s}^{-1}$, but Synechococcus has a mechanism of photo-adaptation, which also permits cell growth and photosynthetic activity at high irradiances. Other environmental conditions such as nutrient concentration, temperature and biological interactions also affect cell-specific growth rates. Weisse (1993) summarized APP growth rates, measured with different methods, in lakes along a trophic gradient, and values ranged from 0.10 to $2.14 \mathrm{~d}^{-1}$. Data from Lake Biwa, Japan (Nagata et al. 1996) and Lake Baikal, Russia (Nagata et al. 1994) estimated APP growth rates using dilution culture experiment, as 0.65 $\mathrm{d}^{-1}$ and $0.3-0.4 \mathrm{~d}^{-1}$, respectively. In Lake Kinneret, Israel, values from 0.29 to $0.60 \mathrm{~d}^{-1}$ have been measured (Malinsky-Rushansky et al. 1995). The maximum net growth rates of unicellular picocyanobacteria in oligotrophic Lake Stechlin, Germany, was $0.23 \mathrm{~d}^{-1}$, corresponding to a biomass doubling every three days ( $\mathrm{Pa}-$ disák et al. 1997). In Lake Maggiore, Italy, Callieri et al. (1996) obtained 0.28-1.14 $\mathrm{d}^{-1}$ net growth and 0.91$2.36 \mathrm{~d}^{-1}$ as potential growth rate for APP using the FDC method.

Biological processes like grazing, viral lysis, parasitism, aggregation and sedimentation can be responsible for high APP loss rates, and result in a potential loss of more than half of picoplanktonic gross carbon production. Suttle (1994) indicates that cyanophages are responsible for 5 to $7 \%$ of Synechococcus lysis in marine systems, and this proportion could increase dramatically depending on host abundance, water temperature and phosphate status of the cell, all important factors affecting phage-host interactions (Wilson et al. 1996).

Stockner et al. (2000a) summarize the present knowledge on growth of picocyanobacteria in natural freshwater systems as follows:

- doubling times of Synechococcus-type natural populations range from 7 hours to 7 days;

- light influences growth, which in turn is tightly coupled with diel cycle;

- a diel pattern could be triggered by an endogenous clock;

- growth rates are discontinuous and controlled by predation and other losses.

Heterotrophic, as well as mixotrophic nanoflagellate and small ciliates, are the most important APP grazers (Stockner \& Antia 1986; Bird \& Kalff 1987; Sanders et al. 1989; Weisse et al. 1990; Christoffersen 1994; Šimek et al. 1995). Among ciliates, oligotrich species and some scuticociliates, which are sometimes at the borderline between nano and microplankton $(<30 \mu \mathrm{m})$, can be important picoplanktivores in lakes (Šimek et al. 1995). Pernthaler et al. (1996) found that heterotrophic nanoflagellates (HNF) are responsible for $90 \%$ of protozoan picoplankton (APP plus bacteria) grazing, whereas ciliates accounted for only $10 \%$. Their data demonstrate that HNF as well as ciliates prefer APP over bacteria in 
all cases studied, but others have noted a marked protozoan feeding selectivity for bacteria over picocyanobacteria (Caron et al. 1991). The prevalence of highly specialized bacteria feeders, such as choanoflagellates, among the HNF community results in a higher consumption of bacteria than APP.

Simek et al. (1996) summarized three ecological categories of freshwater ciliates displaying different feeding strategies and decreasing importance of picosize prey in their diet. There are some very active picoplankton grazers among the more efficient suspension feeders such as Vorticella aquadulcis, Halteria grandinella, Cyclidium spp. and Strobilidium hexachinetum. These protozoa are able to graze 560, 210, 80, 76 APP cell ${ }^{-1} \mathrm{~h}^{-1}$, respectively, with clearence rates reaching values of $3 \mu \mathrm{lcell}^{-1} \mathrm{~h}^{-1}$ (Šimek et al. 1996). Some raptorial feeders such as Urotricha and Balanion planktonicum have grazing rates of 2 and 0.2 APP cell ${ }^{-1} \mathrm{~h}^{-1}$ and clearence rates around $10 \mathrm{nl} \mathrm{cell}{ }^{-1} \mathrm{~h}^{-1}$ (Šimek et al. 1996).

Both predator selection of prey size and feeding mechanisms have been discussed in studies on zooplankton and other organisms (Vanderploeg 1990; Burns \& Schallenberg 1996). Monger \& Landry (1992) demonstrated that clearance rates increase linearly with prey diameter in the prey range 0.7-1.4 $\mu \mathrm{m}$, and Pernthaler et al. (1996) demonstrated, by a selectivity index, that picocyanobacteria are ingested preferentially over bacteria by protozoan predators associated more with size than quality of prey. A possible pitfall of this approach could be differences in palatability of picocyanobacteria and bacteria. Other authors have estimated grazing rates on picocyanobacteria during both the day and night (Ning \& Vaulot 1992; Liu 1990), and obtained higher grazing rates during the day (when the cell size is smaller), giving strong support to the hypothesis of Pernthaler et al. (1996). Dolan \& Šimek (1999) found that HNF had a major control over cells that were not in active division; which is exactly the opposite of what protozoa do with bacterial prey (Gonzales et al. 1990; Sherr et al. 1992; Epstein \& Shiaris 1992). That is to say that APP are grazed preferentially in their "non-dividing phase", while heterotrophic picoplankton are consumed in the "dividing-phase". Thus, protozoa can graze cells in the $0.2-2 \mu \mathrm{m}$ size range but select for a specific size range. Future research must determine if selection of the preferred prey-size is associated also with a strain-type preference so that the concept of a size-refuge proposed for the dividing cell during the day-cycle (Dolan \& Šimek 1999) could be extended to a morpho-refuge as well.

Grazing rates are balanced by growth rates and have a pronounced diel pattern related to prey size. In a review Weisse (1993) generalizes that grazing loss-rates are similar or somewhat lower than growth rates, while Nagata et al. (1994) noted that grazing mortality of cyanobacteria in Lake Biwa are in balance with growth rates, i.e. $0.58 \mathrm{~d}^{-1}$ in reference to predators $<2 \mu \mathrm{m}$ and $1.03 \mathrm{~d}^{-1}$ for predators $<20 \mu \mathrm{m}$. In Lakes Huron and Michigan, grazing losses ranged from 0.1 to $0.7 \mathrm{~d}^{-1}$ (Fahnenstiel et al. 1991a), and in Lake Constance, Germany, Weisse (1988) measured values of 0.05-1.27 $\mathrm{d}^{-1}$. Picoplankton grazing losses can vary widely seasonally and are tightly coupled to growth rates.

\subsection{Role in microbial food web}

The APP community, particularly the picocyanobacteria, can play an important role in the functioning of the microbial loop (Porter et al. 1985; Šimek et al. 1995). Furthermore, an increase in APP carbon production can affect all trophic level, including fish (Stockner \& MacIsaac 1996). Therefore, APP are considered important templates of assimilable carbon biomass at the base of the microbial food web.

Current models of planktonic microbial food webs are based on the presence or absence of Daphnia, a keystone species and superior competitor/predator of protozoans and rotifers for algae (Stockner \& Porter 1988; Porter et al. 1988). Among mesozooplankton, Daphnia can feed on a wide particle size-range (1-50 $\mu \mathrm{m})$ including APP (Stockner \& Porter 1988; Gophen \& Geller 1984). Together with Daphnia, several other cladoceran genera, e.g. Bosmina, Eubosmina and Ceriodaphnia can ingest APP directly (reviewed by Weisse 1993). Whether copepods can graze and assimilate APP remains unanswered since first proposed (Stockner \& Antia 1986). There are many direct-link organisms, dependent on APP, bacteria and protozoans as prey that eventually contribute carbon to the "classical" food web. For example, rotifers can directly grazing APP (Stockner \& Shortred 1989) or can exert a control on HNF as demonstrated by the significant inverse correlation of HNF biomass with rotifer abundance (Pernthaler et al. 1996). As Stockner and Antia asserted (1986), "picocyanobacteria are in a size range suitable for utilization by nauplii and early copepodite stages of copepods as well as rotifers".

Nevertheless, protozoa are the predominant organisms of micobial food webs feeding directly on APP. Carbon flux from protozoa to zooplankton has been measured in only a few lakes. In Lake Biwa, Japan, carbon flux estimates indicated that only $2 \%$ of the total carbon channelled from APP through nanoflagellates, passed to mesozooplankton (Nagata et al. 1996). Other studies demonstrated an efficient carbon flux from picoplankton (including bacteria) to zooplankton in Lake Michigan (Carrick et al. 1991).

The picoplankton-based microbial food web dominates oligotrophic lakes and has many links, is trophically inefficient, and is characterized by a low carbon contribution from "new" production (Stockner \& Porter 1988; Stockner et al. 2000b). In eutrophic lakes picoplankton also plays a major role, especially so if large inedible phytoplankton such as dinoflagellates, colonial 
cyanobacteria and chain-forming or clustered, colonial diatoms prevail (Weisse \& Stockner 1993).

\section{CONCLUDING REMARKS}

Since the discovery of phototrophic picoplankton in the late 1970s our understanding of their taxonomy, physiology and ecology has increased rapidly. APP are key players in carbon production in all aquatic ecosystems, including extreme environments such as ice-covered and/or warm tropical lakes, thermal springs and even in aerial environments, and as autotrophs they often form the base of complex microbial food webs, becoming prey for a multitude of protozoan and micro-invertebrate grazers, that channel APP carbon to higher trophic levels including fish. There are no longer cogent arguments regarding the idea of "links" or "sinks" in aquatic food webs, nor about their efficiency in passing carbon to higher trophic levels.

New perspectives on APP ecology will continue to rely on application of new molecular methods to study genetic diversity, and these advances should improve our understanding of APP spatiotemporal variation and succession within a wide variety of aquatic habitats. There is need for improved studies of mechanisms that trigger colonial morphs from common single-celled species, and also to determine whether these are governed by endogenous or exogenous factors.

How will higher levels of UV-B radiation forecast to accompany global climate warming affect APP populations in lakes and oceans? Will a warmer and more strongly stratified and severely nutrient depleted euphotic zone in lakes and oceans further reduce pelagic carbon production and increase the presence of APP based "microbial" food webs? Will their presence portend imminent "oligotrophication" resulting in less efficient carbon flows within pelagic ecosystems with resultant declining fish production in lakes and oceans?

Finally, there must be continued support for longterm studies on single-celled APP, but more importantly new studies focused on colonial APP, whose ecology is so poorly understood, must be initiated, for without these initiatives there will be less reliable prediction of APP population responses to an uncertain, but likely, much warmer climatic future in the this new millenium. How will APP adapt to global warming and higher UV radiation? How will global pelagic fisheries be affected? Will the pelagic ecosystems of the temperate oceans and inland freshwaters of the next century return to APP dominance? These are fair questions because APP are the most ancient, extant survivors of primordial seas and also the primary carbon producers of aquatic ecosystems and, like no other major algal group, capable of adapting to extreme environments. These are crucial questions that need answers if the quality and integrity of freshwater and global ocean ecosystems are to be preserved, let alone the viability of the human genome on earth.

\section{REFERENCES}

Azam, F., T. Fenchel, J.G. Field, J.S. Gray, L.A. Meyer-Reil \& F. Thingstad. 1983. The ecological role of water-column microbes in the sea. Mar. Ecol. Prog. Ser., 10: 257263.

Bailey-Watts, A.E., M.E. Bindloss \& J. H. Belcher. 1968. Freshwater primary production by a blue-green alga of bacterial size. Nature, 220: 1344-1345.

Bell, T. \& J. Kalff. 2001. The contribution of picophytoplankton in marine and freshwater systems of different trophic status and depth. Limnol. Oceanogr., 46(5): 12431248.

Bertoni, R. \& C. Callieri. 1989. Organic matter and decomposers in Lago Maggiore: a pluriannual study. Mem. Ist. ital. Idrobiol., 46: 145-172.

Bird, D.J. \& J. Kalff. 1987. Algal phagotrophy: regulating factors and importance relative to photosynthesis in Dinobryon (Chrysophyceae). Limnol. Oceanogr., 32: 277-284.

Bloem, J.M., J.B. Bar-Gilissen \& T.E. Cappenberg. 1986. Fixation, counting and manipulation of heterotrophic nanoflagelates. Appl. Environ. Microbiol., 52: 1266-1272.

Boraas, M.E., D.W. Bolgrien \& D.A. Holen. 1991. Determination of eubacterial and cyanobacterial size and number in Lake Baikal using epifluorescence. Int. Revue. ges. Hydrobiol., 76: 537-544.

Burger-Wiersma, T. 1991. Prochlorothrix hollandica: a filamentous prokaryotic species containing chlorophylls $a$ and b. Algological Studies, 64: 555-558.

Burger-Wiersma, T., M. Veenhuis, H.J. Korhals, C.C.M. van der Wiel \& L.R. Mur. 1986. A new prokaryote containing chlorophylls $a$ and $b$. Nature, 320: 262-264.

Burns, C.W. \& J.G. Stockner. 1991. Picoplankton in six New Zealand lakes: abundance in relation to season and trophic state. Int. Revue ges. Hydrobiol., 76: 523-536.

Burns, C.W. \& M. Schallenberg. 1996. Relative impacts of copepods, cladocerans and nutrients of the microbial food web of a mesotrophic lake. J. Plankton Res., 18(5): 683714

Callieri C. \& R. Piscia. (2002). Photosynthetic efficiency and seasonality of autotrophic picoplankton in Lago Maggiore after its recovery. Freshwat. Biol:: (in press).

Callieri, C. \& J. Stockner. 2000. Picocyanobacteria success in oligotrophic lakes: fact or fiction? J. Limnol., 59 (1): 7276.

Callieri, C. \& M.L. Pinolini. 1995. Picoplankton in Lake Maggiore, Italy. Int. Revue. ges. Hydrobiol., 80: 491-501.

Callieri, C. 1996. Extinction coefficient of red, green and blue light and its influence on picocyanobacterial types in lakes at different trophic levels. Mem. Ist. ital. Idrobiol., 54: $135-142$.

Callieri, C., E. Amicucci, R. Bertoni \& L. Vörös. 1996. Fluorometric characterization of two picocyanobacteria strains from different underwater light quality. Int. Revue ges. Hydrobiol., 81: 13-23.

Callieri, C., R. Bertoni, E. Amicucci, M.L. Pinolini \& I. Jasser. 1996. Growth rates of freshwater picocyanobacteria measured by FDC: problems and potentials for the estimation of picoplankton organic carbon synthesis. Arch. Hydrobiol. Spec. Issues Advances Limnol., 48: 93-103

Campbell, L. \& E.J. Carpenter. 1986. Estimating the grazing pressure of heterotrophic nanoplankton on Synechococcus spp. using the seawater dilution and selective inhibitor techniques. Mar. Ecol. Prog. Ser., 33: 121-129.

Campbell, L. \& R. Iturriaga. 1988. Identification of Synechococcus spp. in the Sargasso Sea by immunofluorescence and fluorescence excitation spectroscopy performed on individual cells. Limnol. Oceanogr., 33:1196-1201.

Campbell, L., H.A. Nolla \& D. Vaulot. 1994. The importance of Prochlorococcus to community structure in the central North Pacific Ocean. Limnol. Oceanogr., 39(4): 954-961. 
Caron, D.A., E.L. Lim ,G. Miceli, J.B. Waterbury \& F.W. Valois. 1991. Grazing and utilization of chroococcoid cyanobacteria and heterotrophic bacteria by protozoa in laboratory cultures and a coastal plankton community. Mar. Ecol. Prog. Ser., 76: 205-217.

Caron, D.A., F.R. Pick \& D.R.S. Lean. 1985. Chroococcoid cyanobacteria in Lake Ontario: seasonal and vertical distribution during 1982. J. Phycol., 21: 171-175.

Carrick, H.J., G.L. Fahnenstiel, E.F. Stoermer \& R.G. Wetzel. 1991. The importance of zooplankton-protozoan trophic couplings in Lake Michigan. Limnol. Oceanogr., 36: 1335-1345.

Chisholm, S.W. 1992. Phytoplankton size. In: P.G. Falkowski \& A.D. Woodhead (Eds), Primary productivity and biogeochemical cycles in the sea. Plenum Press, NY: 213237.

Chisholm, S.W., E.V. Armbrust \& R.J. Olson. 1986. The individual cell in phytoplankton ecology: cell cycle and applications of flow cytometry. In: T. Platt \& W.K. Li (Eds), Photosynthetic picoplankton. Can. Bull. Fish. Aquat. Sci., 214: 343-369.

Chisholm, S.W., R.J. Olson, E.R. Zettler, R. Goericke, J.B. Waterbury \& N.A. Welschmeyer. 1988. A novel free living prochlorophyte abundant in the oceanic euphotic zone. Nature, 334: 340-343.

Christoffersen, K. 1994. Variation of feeding activities of heterotrophic nanoflagellates on picoplankton. Mar. Microb. Food-Web, 8: 111-123.

Craig, S.R. 1985. Distribution of algal picoplankton in some European freshwaters. Abstr. $2^{\text {nd }}$ Int.Phycol.Congr., Copenhagen Aug. 1985: 31.

Daley, R.J., \& J.E. Hobbie. 1975. Direct counts of aquatic bacteria by a modified epifluorescence technique. Limnol. Oceanogr., 20: 875-882.

Danish Standard Association. 1982. Water Quality-Incubator method for determining the carbon assimilation by plankton algae using ${ }^{14} \mathrm{C}$ technique. Dansk Standard, DS/R 293.

Davis P.G., \& J.McN. Sieburth. 1982. Differentiation of phototrophic and heterotrophic nanoplankton populations in marine waters by epifluorescence microscopy. Ann. Inst. Ocèanogr., 58: 249-260.

Dolan, J. \& K. Šimek. 1999. Diel periodicity in Synechococcus populations and grazing by heterotrophic nanoflagellates: analysis of food vacuole contents. Limnol. Oceanogr., 44: 1565-1570.

Douglas, S.E. \& N. Carr. 1988. Examination of genetic relatedness of marine Synechococcus spp. By using restriction fragment length polymorphysms. Appl. Environ. Microbiol., 54 (12): 3071-3078.

Dussart, B.H. 1965. Les different categories de plancton. Hydrobiologia, 26: 72-74.

Dussart, B.H. 1966. Limnologie. L'étude des eaux continentales. Gauthier - Villars, Paris: $667 \mathrm{pp}$.

Eilers, P.H.C. \& J.C.H. Peeters. 1988. A model for the relationship between light intensity and the rate of photosynthesis in phytoplankton. Ecological Modelling., 42: 199215.

Epstein, S.S. \& M.P. Shiaris. 1992. Size-selective grazing of coastal bacterioplankton by natural assemblages of pigmented flagellates, colorless flagellates, and ciliates. Microb. Ecol., 23: 211-225.

Epstein, S.S., \& J. Rossel. 1995. Methodology of in situ grazing experiments: evaluation of a new vital dye for preparation of fluorescently labeled bacteria. Mar. Ecol. Prog. Ser., 128: 143-150.

Ernst A. 1991. Cyanobacterial picoplankton from Lake Constance.I. Isolation by fluorescence characteristics. $J$. Plankton Res., 13: 1307-1312.

Ernst A., C. Postius C. \& P. Böger. 1996. Glycosylated surface proteins reflect genetic diversity among Synechococ- cus species of Lake Constance. Arch. Hydrobiol. Spec. Issues Advanc. Limnol., 48: 1-6.

Ernst A., P. Marschall \& C. Postius. 1995. Genetic diversity among Synechococcus spp. (cyanobacteria) isolated from the pelagial of Lake Costance. FEMS Microbiol. Ecol., 17: 197-204.

Fahnenstiel, G.L. \& H.J. Carrick. 1992. Phototrophic picoplankton in lakes Huron and Michigan: abundance, distribution, composition and contribution to biomass and production. Can. J. Fish. aquat. Sci., 49: 379-388.

Fahnenstiel, G.L., D.G. Redalje \& S.E. Lohrenz. 1994. Has the importance of photoautotrophic picoplankton been overestimated? Limnol. Oceanogr., 39: 432-438.

Fahnenstiel, G.L., H.J. Carrick \& R. Iturriaga. 1991a. Physiological characteristics and food web dynamics of Synechococcus in Lakes Huron and Michigan. Limnol. Oceanogr., 36 (2): $219-234$

Fahnenstiel, G.L., H.J. Carrick, C.E. Rogers \& L. Sicko-Goad. 1991b. Red fluorescing phototrophic picoplankton in the Laurentian Great Lakes: what are they and what are they doing? Int. Revue ges. Hydrobiol., 76: 603-616

Fahnenstiel, G.L., T.R. Patton, H.J. Carrick \& M.J. McCormick. 1991c. Diel division cycle and growth rates of Synechococcus in lakes Huron and Michigan. Int. Revue ges. Hydrobiol., 76: 657-664.

Gächter, R. 1972. Die Bestimmung der Tagesraten der plankischen Primärproduktion-Modelle und in situ messungen. Sweiz. Z. Hydrol., 34: 211-244.

Gaedke, U. \& T. Weisse. 1998. Seasonal and interannual variability of picocyanobacteria in Lake Costance. Arch. Hydrobiol. Spec. Issues Advanc. Limnol., 53: 143-158.

Gieskes, W.W.C. \& G.W. Kraay. 1983. Unknown chlorophyll $a$ derivatives in the North Sea and tropical Atlantic Ocean revealed by HPLC analysis. Limnol. Oceanogr., 28: 757766.

Goericke, R. \& D.J. Repeta. 1993. Chlorophyll a and b and divinyl chlorophyll $a$ and $b$ in the open subtropical North Atlantic Ocean. Mar. Ecol .Prog. Ser., 101: 307-313.

Gonzalez, J.M., E.B. Sherr \& B.F. Sherr. 1990. Size-selective grazing on bacteria by natural assemblages of estuarine flagellates and ciliates. Appl. Environ. Microbiol., 56:583589

Gophen, M. \& W. Geller. 1984. Filter mesh size and food particle uptake by Daphnia. Oecologia, 64: 408-412.

Hall, J.A. \& W.F. Vincent. 1994. Vertical and horizontal structure of the picophytoplankton community in a stratified coastal system off New Zealand. N.Z. J. Mar. Freshwater Res., 28 (3): 299-308.

Hall, J.A. 1991. Long-term preservation of picophytoplankton for counting by fluorescence microscopy. Br. Phycol. J., 26: $169-176$.

Hawley, G.R.W. \& B.A.Whitton. 1991. Survey of algal picoplankton from lakes in five continents. Verh. int. Ver. Limnol., 24: 1220-1222.

Hayat, M.A. 1981. Fixation for electron microscopy. Academic press. NY: $500 \mathrm{pp}$.

Hooks, C.E., R.R. Bidigare, D.M. Keller \& R.R.L. Guillard. 1988. Coccoid eukaryotic marine ultraplankters with four different HPLC pigment signatures. J. Phycol., 24: 571580.

Huang, T.C., J. Tu, J.T. Chow \& T.H. Chen. 1990. Circadian rhythm of the prokaryote Synechococcus sp. RF-1. Plant. Physiol., 92: 531-533.

Hutchinson, G.E. 1967. A Treatise on Limnology, II. Introduction to lake biology and the limnoplankton. John Wiley \& Sons, NY: 1115 pp.

Iturriaga, R. \& B.G. Mitchell. 1986. Chroococcoid cyanobacteria: a significant component in the food web dynamics of the open ocean. Mar. Ecol. Prog. Ser., 28: 291-297.

Johnson, P.W. \& J. Sieburth. 1982. In-situ morphology and occurrence of eukaryotic phototrophs of bacterial size in 
the picoplankton of estuarine and oceanic waters. $J$. Phycol., 18: 318-327.

Kana, T.M. \& P.M. Glibert. 1987a. Effect of irradiances up to $2000 \mu \mathrm{E} \mathrm{m}^{-2} \mathrm{~s}^{-1}$ on marine Synechococcus WH7803-I. Growth, pigmentation, and cell composition. Deep Sea Res., 34: 479-495.

Kana, T.M. \& P.M. Glibert. 1987a. Effect of irradiances up to $2000 \mu \mathrm{E} \mathrm{m}^{-2} \mathrm{~s}^{-1}$ on marine Synechococcus WH7803 -II. Photosynthetic responses and mechanisms. Deep Sea Res., 34: 497-516.

Kiørboe, T. \& J. Hansen. 1993. Phytoplankton aggregate formation: observations of patterns and mechanisms of cell sticking and the significance of exopolymeric material. $J$. Plankton Res., 15: 993-1018.

Kirchman, D.L. 1993. Statistical analysis of direct counts of microbial abundance. In: P.F. Kemp, B.F. Sherr, E.B Sherr \& J.J. Cole (Eds), Handbook of methods in aquatic microbial ecology. Lewis Publ.: 117-121.

Klut, M.E. \& J.G. Stockner. 1991. Picoplankton associations in an ultra-oligotrophic lake on Vancouver Island ,British Columbia. Can. J. Fish. aquat. Sci., 48 (6): 1092-1099.

Komárek, J. 1996. Towards a combined approach for the taxonomic and species delimitation of picoplanktic cyanoprokaryotes. Algol. Studies, 83: 377-401.

Kondo, T., C.A. Strayer, R.D. Kulkarni, W. Taylor, M. Ishiur, S.S. Golden \& C.H. Johnson. 1993. Circadian rhythms in prokaryotes: luciferase as a reporter of circadian gene expression in cyanobacteria. Proc. Natl. Acad. Sci. US, 90: $5672-5676$

Kuuppo-Leinikki, P. \& H. Kuosa. 1989. Preservation of picoplanktonic cyanobacteria and heterotrophic nanoflagellates for epifluorescence microscopy. Arch. Hydrobiol., 114: 631.

Landry, M.R., J. Kirshtein \& J. Constantinou. 1995. A refined dilution technique for measuring the community grazing impact of microzooplankton with experimental tests in the Central Equatorial Pacific. Mar. Ecol. Prog. Ser., 120: 5363.

Li, W.K.W. 1986. Experimental approaches to field measurements: methods and interpretation.. In: T. Platt \& W.K. Li (Eds) Photosynthetic picoplankton. Can. Bull. Fish. aquat. Sci., 214: 251-286

Liu, H., L. Campbell \& M.R. Landry. 1995. Growth and mortality rates of Prochlorococcus and Synechococcus measured with a selective inhibitor technique. Mar. Ecol. Prog. Ser., 116: 277-287.

Liu, Z. 1990. Estimating the grazing pressure of heterotrophic nanoplankton on Synechococcus spp. in the surface coastal water using selective inhibitor techniques. Dongay-Mar. Sci., 8: 49-54.

Lohmann, H. 1911. Über das Nannoplankton und die zentrifugierun kleinsten Wasseproben zur gewinnung desselben in lebendem Zustande. Int. Revue ges. Hydrobiol. Hydrogr., 4: $1-38$.

MacIsaac, E.A. \& J.G. Stockner. 1993. Enumeration of phototrophic picoplankton by autofluorescence microscopy. In: P.F. Kemp, B.F. Sherr, E.B. Sherr \& J.J. Cole (Eds), Handbook of methods in aquatic microbial ecology. Lewis Publ.: 187-197.

Maeda, H., A. Kawai \& M.M. Tilzer. 1992. The water bloom of cyanobacterial picoplankton in Lake Biwa, Japan. Hydrobiologia, 248: 93-103.

Malinsky-Rushansky, N. \& T. Berman. 1991. Picocyanobacteria and bacteria in Lake Kinneret. Int. Revue ges. Hydrobiol., 76(4): 555-564.

Malinsky-Rushansky, N., T. Berman \& Z. Dubinsky, 1995. Seasonal dynamics of picophytoplankton in Lake Kinneret, Israel. Freshwater Biol., 34: 241-254.

Malone, T.C. 1980. Algal size. In: I. Morris (Ed.), The physiological ecology of phytoplankton. Studies in Ecology. Vol.7. Blackwell Sci. Publ.: 433-463.
Margalef, R. 1955. Los organismos indicadores en la limnologia. Biologia de las aguas continentales. XII. Min de Agricult. Inst. Forest. Invest. Exper., Madrid: 300 pp.

McKenzie, C.H., R. Helleur \& D. Deibel. 1992. Use of inorganic membrane filters (Anopore) for epifluorescence and scanning electron microscopy of nanoplankton and picoplankton. Appl. Environ. Microbiol., 58 (2): 773-776.

McMurther, H.J.C. \& F. Pick. 1994. Fluorescence characteristics of a natural assemblage of freshwater picocyanobacteria. J. Plankton Res., 16 (8): 911-925.

Monger, B.C. \& M.R. Landry. 1992. Size selectivity grazing by heterotrophic nanoflagellates: an analysis using livestained bacteria and dual-beam flow cytometry. Arch. Hydrobiol. Beih. Ergebr. Limnol., 37: 173-185.

Munavar, M. \& G. L. Fahnenstiel. 1982. The abundance and significance of ultraplankton and microalgae at an offshore station in central Lake Superior. Can. Tech. Rep. Fish. aquat. Sci., 1153: 1-13.

Muyzer, G. 1999. DGGE/TGGE a method for identifying genes from natural ecosystems. Current Opinion in Microbiology, 2: 317-322.

Nagata, T., K. Takai, K. Kawanobe, D. Kim, R. Nakazato, N. Guselnikova, N. Bondarenko, O. Mologawaya, T. Kostrnova, V. Drucker, Y. Satoh \& Y. Watanabe. 1994. Autotrophic picoplankton in southern Lake Baikal: abundance growth and grazing mortality during summer. J. Plankton Res., 16: 945-959.

Nagata, T., K. Takay, K. Kawabata, M. Nakanishi \& J. Urabe. 1996. The trophic transfer via a picoplankton-flagellatecopepod food chain during a picocyanobacterial bloom in Lake Biwa. Arch. Hydrobiol., 137: 145-160.

Ning, X., \& D. Vaulot. 1992. Estimating Synechococcus spp growth rates and grazing pressure by heterotrophic nanoplankton in the English channel and the Celtic Sea. ActaOceanol. Sin., 11: 255-273.

Olson, R.J., D. Vaulot \& S.W. Chisholm.1985. Marine phytoplankton distributions measured using shipboard flow citometry. Deep Sea Res., 32: 1273-1280.

Padisák, J., L. Krienitz, R. Koschel \& J. Nedoma. 1997. Deeplayer autotrophic picoplankton maximum in the oligotrophic Lake Stechlin, Germany: origin, activity, development and erosion. Eur. J. Phycol., 32: 403-416.

Park, R.B., J. Kelley, S. Drury \& K. Sauer. 1966. The Hill reaction of chloroplasts isolated from glutaraldehyde-fixed spinach leaves. Proc. Natl. Acad. Sci. USA, 55: 1056.

Passoni, S. \& C. Callieri. 2000. Picocyanobacteria single forms, aggregates and microcolonies: survival strategy or species succession? Verh. int. Ver. Limnol., 27: 18791883.

Passoni, S., C. Callieri \& S. Heinimaa. 1997. Dinamiche di distribuzione del picoplancton autotrofo nel Lago Maggiore. In: M. Piccazzo (Ed.), Proceedings $12^{\circ}$ AIOL Congress., Vol 1: 109-118.

Pearl, H.W. 1977. Ultraphytoplankton biomass and production in some New Zealand Lakes, N.Z. J. Mar. Freshwater Res., 11: 297-305.

Pernthaler, J., K. Šimek, B. Sattler, A. Schwarzenbacher, J. Bobkova, \& R. Psenner. 1996. Short-term changes of protozoan control on autotrophic picoplankton in an oligomesotrophic lake. J. Plankton Res., 18: 443-462.

Petersen, R. 1991. Carbon-14 uptake by picoplankton and total phytoplankton in eight New Zealand lakes. Int. Revue ges. Hydrobiol., 76: 631-641.

Pick, F.R. \& C. Bérubé. 1992. Diel cycles in the frequency of dividing cells of freshwater picocyanobacteria. J. Plankton Res., 14: 1193-1198.

Pick, F.R. \& D.A.Caron. 1987. Picoplankton and nanoplankton biomass in Lake Ontario: relative contribution of phototrophic and heterotrophic communities. Can. J. Fish. aquat. Sci., 44: 2164-2172. 
Pick, F.R. \& D.M. Agbeti. 1991.The seasonal dynamic and composition photosynthetic picoplankton comunities in temperate lakes in Ontario, Canada. Int. Revue ges. Hydrobiol., 76: 565-580.

Pick, F.R. 1991. The abundance and composition of freshwater picocyanobacteria in relation to light penetration. Limnol. Oceanogr., 36: 1457-1462.

Platt, T. 1971. The annual production by phytoplankton in St. Margaret's Bay Nova Scotia. J. Cons. int. Explor. Mer., 33: 324-333.

Pomeroy, L.R. 1974. The ocean's food web,a changing paradigm. Bioscience, 24(9): 499-504.

Porter, K.G., E.B. Sherr, B.F. Sherr, M.Pace \& R.W. Sanders. 1985. Protozoa in planktonic food web. J. Protozool., 32: 409-415.

Porter, K.G., H. Pearl, R. Hodson, M. Pace, J. Priscu, B. Riemann, D. Scavia \& J. Stockner. 1988. Microbial interactions in lake food webs. In: S.R. Carpenter (Ed.), Complex interactions in lake communities. Springer-Verlag, New York: 209-228.

Postius, C., A. Ernst, U. Kenter \& P. Böger. 1996. Persistence and genetic diversity among strains of phycoerythrin-rich cyanobacteria from the picoplankton of Lake Constance. J. Plankton Res., 18: 1159-1166.

Raven, J.A. 1986. Physiological consequences of extremely small size for autotrophic organisms in the sea. In: T. Platt \& W.K.W. Li (Eds), Photosynthetic picoplankton. Can. Bull. Fish. aquat. Sci., 214: 1-70.

Reynolds, N. 1973. The estimation of the abundance of ultraplankton. Br. Phycol. J., 8: 135-146.

Rodhe, W. 1955. Productivity: can plankton production proceed during winter darkness in subartic lakes? Int. Ver. Theor. Angew. Limnol. Verh., 12: 117-122.

Rodhe, W. 1958. Primarproduktion und Seetypen. Ver. int. Ver. Limnol., 13: 121-141.

Ross, P.E. \& H.C. Duthie. 1981. Ultraplankton biomass. Productivity and efficiency in Lac Matamec, a precambrian shield lake. J. Phycol., 17: 181-186.

Ruggiu, D., R. Bertoni, C. Callieri, M. Manca \& A. M. Nocentini. 1998. Assessment of biota in lakes from the Khumbo Valley, High Himalayas. In: G. Tartari, R. Baudo \& M. Munavar (Eds), Top of the world environmental research. Ecovision World Monograph Series: 219-233.

Sanders, R.W., K.G. Porter, S.J. Bennet \& A.E. DeBiase. 1989. Seasonal patterns of bacterivory by flagellates, ciliates, rotifers and cladocerans in a freshwater planktonic community. Limnol. Oceanogr., 34: 673-687.

Schallenberg M. \& C.W. Burns. 2001. Tests of autotrophic picoplankton as early indicators of nutrient enrichment in an ultra-oligotrophic lake. Freshwater Biol., 46: 27-37.

Shapiro, L. P., E.M. Haugen, D.M. Keller, R.R. Bidigare, L. Campbell \& R.R.L. Guillard.1989. Taxonomic affinities of marine coccoid ultraplankton: a comparison of immunochemical surface antigen cross-reactions and HPLC chloroplast pigment signatures. J. Phycol., 25:794-797.

Sherr, B.F., E.B. Sherr \& J. McDaniel. 1992. Effect of protistan grazing on the frequency of dividing cells in bacterioplankton assemblages. Appl. Environ. Microbiol., 58: 2381-2385.

Sherr, E.B. \& B.F. Sherr. 1993. Protistan grazing rates via uptake of fluorescently labeled prey. In: P. Kemp, B. Sherr, E. Sherr \& J. Cole (Eds), Handbook of methods in aquatic microbial ecology. Lewis Publ., Boca Raton, FL: 695-701.

Sherr, E.B., B.F. Sherr, T. Berman \& O. Hadas. 1991. High abundance of picoplankton-ingesting ciliates during late fall in Lake Kinneret, Israel. J Plankton Res., 13: 789-799.

Sicko-Goad, L. \& E.F. Stoermer. 1984. The need for uniform terminology concerning phytoplankton cell size fractions and examples of picoplankton from the lauretian great lakes. J. Great Lakes Res., 10 (1): 90-93.
Sieburth, J.McN., V. Smetacek \& J. Lenz. 1978. Pelagic ecosystem structure: heterotrophic compartments of the plankton and their relationship to plankton size fractions. Limnol. Oceanogr., 23 (6): 1256-1263.

Šimek, K, M. Macek, J. Pernthaler, V. Straskrabová and R. Psenner. 1996. Can freshwater planktonic ciliates survive on a diet of picoplankton? J. Plankton Res., 18: 597-613.

Šimek, K., J. Bobkova, M. Macek, J. Nedoma \& R. Psenner. 1995. Ciliate grazing on picoplankton in a eutrophic reservoir during the summer phytoplankton maximum: a study at the species and community level. Limnol. Oceanogr., 40: $1077-1090$.

Smayda, T.J. 1974. Some experiment on the sinking characteristics of two freshwater diatoms. Limnol. Oceanogr., 19: 628-635.

Søndergaard, M. 1991. Phototrophic picoplancton in temperate lakes: seasonal abundance and importance along a trophic gradient. Int. Revue. ges. Hydrobiol., 76(4): 505-522.

Steeman Nielsen, E. 1951. Measurment of the production of organic matter in the sea by means of carbon-14. Nature. 167: 684-685.

Steeman Nielsen, E. 1952. The use of radioactive carbon (14C) for measuring organic production in the sea. $J$. Cons. Int. Explor. Mer., 18: 117-140.

Stockner, J., C. Callieri, \& G. Cronberg. 2000a. Picoplankton and other non-bloom forming cyanobacteria in lakes. In: B. Whitton \& M. Potts, (Eds), The Ecology of Cyanobacteria: Their Diversity in Time and Space. Kluwer Academic Publishers: 195-238.

Stockner, J.G., E. Rydin \& P. Hyenstrand. 2000b. Cultural oligotrophication: causes and consequences for fisheries resources. Fisheries, 25: 7-14.

Stockner, J.G. \& E.M. MacIsaac. 1996. British Columbia lake enrichment programme: two decades of habitat enhancement for sockeye salmon. Reg. Rivers Res. Manage., 12: 547-561.

Stockner, J.G. \& K.G. Porter. 1988. Microbial food webs in freshwater planktonic ecosystems. In: S.R. Carpenter (Ed.), Complex interactions in lake communities. Springer-Verlag: 69-83.

Stockner, J.G. \& K.S. Shortreed. 1989. Algal picoplankton and contribution to food webs in oligotrophic British Columbia Lakes. Hydrobiologia, 173: 151-166.

Stockner, J.G. \& K.S. Shortreed. 1991. Autotrophic picoplankton: community composition abundance and distribution across a gradient of oligotrophic British Columbia and Yukon Territory lakes. Int. Revue ges. Hydrobiol., 76: 581-601.

Stockner, J.G. \& K.S. Shortreed. 1994. Autotrophic picoplankton comunity dynamics in a prealpine lake in British Columbia, Canada. Hydrobiologia, 274: 133-142.

Stockner, J.G. \& N.J. Antia. 1986. Algal picoplankton from marine and freshwater: a multidisciplinary perspective. Can. J. Fish. aquat. Sci., 43: 2472-2503.

Stockner, J.G. 1988. Phototrophic picoplankton: an overview from marine and freshwater ecosystems. Limnol. Oceanogr., 33(4): 765-775.

Stockner, J.G. 1991. Autotrophic picoplankton in freshwater ecosystems: the view from the summit. Int. Rev. ges. Hydrobiol., 76: 483-492.

Stockner, J.G. \& K.G. Porter. 1988. Microbial food webs in freshwater planktonic ecosystems. In: S.R. Carpenter (Ed.), Complex interactions in lake communities. Springer-Verlag, New York, NY: 69-84.

Stockner, J.G., M.E. Klut \& W.P. Cochlan. 1990. Leaky filters: a warning to aquatic ecologists. Can. J. Fish. aquat. Sci., 47: 16-23.

Suttle, C.A. 1994. Dynamics and distribution of cyanophages and their effect on marine Synechococcus sp. Appl. Environ. Microbiol., 60: 3167-3174. 
Sweeney, B.M. \& M.B. Borgese. 1989. A circadian rhythm in cell division in a prokaryote, the cyanobacterium Synechococcus WH7803. J. Phycol., 25: 183-186.

Takahashi, M \& T. Hori. 1984. Abundance of picophytoplankton in the subsurface chlorophyll maximum layer in subtropical and tropical waters. Mar. Biol., 79:177-186.

Throndsen, J. 1978. Productivity and abundance of ultra-and nanoplankton in Oslofjorden. Sarsia, 63: 273-284.

Vandamme, P. B. Pot, M.Gillis, P. DeVos, K. Kersters \& J. Swings. 1996. Polyphasic taxonomy, a consensus approach to bacterial systematics. Microbiol. Rev., 60: 407438 .

Vanderploeg, H.A. 1990. Feeding mechanisms and particles selection in suspension-feeding zooplankton. In: R.S. Wotton (Ed.), The biology of particles in aquatic systems. CRC Press, Boston: 183-212.

Vaulot, D., F. Partensky, J. Neveux, R.F.C. Mantoura \& C.A. Llewellyn. 1990. Winter presence of prochlorophytes in surface waters of the northwestern Mediterranean Sea. Deep Sea Res., 39: 727-742.

Veldhuis, M.J.W. \& G.W. Kraay. 1990. Vertical distribution and pigment composition of a picoplanktonic prochlorophyte in the subtropical N.Atlantic: a combined study of HPLC-analysis of pigments and flow citometry. Mar. Ecol. Prog. Ser., 68:121-127.

Veldhuis, M.J.W. \& G.W. Kraay. 1993. Cell abundance and fluorescence of picoplankton in relation to growth irradiance and nitrogen availability in the Red Sea. Neth. J. Sea Res., 31: 135-145.

Verduin, J. 1956. Energy fixation and utilization by natural communities in western Lake Erie. Ecology, 37: 40-49.

Vincent, W.F. 2000. Cyanobacterial dominance in the polar regions. In: B. Whitton \& M. Potts (Eds), The Ecology of Cyanobacteria: Their Diversity in Time and Space. Kluwer Academic Publishers: 321-340.

Vollenweider, R.A. 1965. Calculation models of photosynthesis-depth curves and some implications regarding day rate estimates in primary production. Mem. Ist. ital. Idrobiol., 18 Suppl.: 425-457.

Vollenweider, R.A., M. Munavar \& P. Stadelmann. 1974. A comparative review of phytoplankton and primary production in the Laurentian Great Lakes. J. Fish. Res. Board Can.,31: 739-762.

Vörös, L., C. Callieri, K.V. Balogh \& R. Bertoni. 1998. Freshwater picocyanobacteria along trophic gradient and light quality range. In: M. Alvarez-Cobelas, C.S. Reynolds, P. Sanchez-Castillo \& J. Kristiansen (Eds), Phytoplankton and trophic gradients. Hydrobiologia, 369/370: 117-125.

Received: July 2001

Accepted: December 2001
Vörös, L., P. Gulyas \& J. Nemeth. 1991. Occurrence, dynamics and production of picoplankton in Hungarian shallow lakes. Int. Revue ges. Hydrobiol., 76: 617-629.

Wall, D. \& F. Briand. 1979. Response of lake picoplankton communities to in situ manipulations of light intensiy and colour. J. Plankton Res., 1: 103-112.

Waterbury, J.B., S.W. Watson, F.W. Valois \& D.G. Franks. 1986. Biological and ecological characterization of the marine unicellular cyanobacterium Synechococcus. Can. Bull. Fish. aquat. Sci., 214: 71-120.

Wehr, J.D. 1993. Effects of experimental manipulation of ligth phosphorus supply on competition among picoplankton and nanoplankton in a oligotrophic lake. Can. J. Fish. aquat. Sci., 50: 936-945.

Weisse, T. \& A. Schweizer. 1991. Seasonal and interannual variation of autotrophic picoplankton in a large prealpine lake (Lake Constance). Verh. int. Ver. Limnol., 24: 821825.

Weisse, T. \& J.G. Stockner. 1993. Eutrophication: the role of microbial food webs. In: R. de Bernardi, R. Pagnotta \& A. Pugnetti (Eds.), Strategies for lake ecosystems beyond 2000. Mem. Ist. ital. Idrobiol., 52: 133-150.

Weisse, T. \& U. Kenter. 1991. Seasonal and annual variation of autotrophic picoplankton in prealpine lake. Int. Revue ges. Hydrobiol., 76: 493-504.

Weisse, T. 1988. Dynamics of autotrophic picoplankton in Lake Constance. J. Plankton Res., 10: 1179-1188.

Weisse, T. 1993. Dynamics of autotrophic picoplankton in marine and freshwater ecosystems. In: J. G. Jones (Ed.), Advances in microbial ecology. 13. Plenum Press: 327370.

Weisse, T., H. Müller, R.M. Pinto-Coelho, A. Schweizer, D. Springmann \& G. Baldringer. 1990. Response of the microbial loop to the phytoplankton spring bloom in a large prealpine lake. Limnol.Oceanogr., 35: 781-794.

Wetzel, R.G. \& G.E. Likens. 1990. Limnological analyses. Springer-Verlag: $389 \mathrm{pp}$.

Wilson, W.H., N.G. Carr \& H.N. Mann. 1996. The effect of phosphate status on the kinetics of cyanophage infection in the oceanic cyanobacterium Synechococcus sp. WH7803. J. Phycol., 32: 506-516.

Wood, A.M. \& D. Townsend. 1990. DNA Polymorphism within the WH7803 serogroup of marine Synechococcus spp. (Cyanobacteria). J. Phycol., 26(3): 576-585.

Wood, A.M., P.K. Horan, K. Muirhead, D.A. Phinney, C.M. Yentsch \& J.B. Waterbury. 1985. Discrimination between types of pigments in marine Synechococcus spp. by scanning spectroscopy, epifluorescence microscopy and flow cytometry. Limnol. Oceanogr., 30: 1303-1315. 